\title{
Interactive theatre for HIV/AIDS side effects on youth sexuality reproductive health and rights in pakistan to learn and practice
}

Sana Sohail

From $16^{\text {th }}$ International Symposium on HIV and Emerging Infectious Diseases

Marseille, France. 24-26 March 2010

\section{Background}

Pakistan has the largest demographic dividend of youth, i.e. $63 \%$ population below the age of 29 (Out of 170 million), but unfortunately majority of the youth are unaware about sexual and Reproductive health and rights and lacks in access to sexuality education and services due to Socio-cultural norms which leads to harmful sex practices, increase rate of STI/RTI including HIV/AIDS and creating myths and misconceptions in their minds.

\section{Methods}

The above stated situation urged Chanan Development Association (CDA); a youth lead NGO Working to empower young people in Pakistan, to launch an innovative program on self-help basis with the title "Interactive Theatre for HIV/AIDS Side effects on Youth Sexuality Reproductive Health and Rights in Pakistan" to Learn and Practice. The main objective of the project was Equipping young activist with the skill of Interactive Theatre (Theatre of the Oppressed) so that they can utilize this skill effectively to educate and sensitize their communities in general and young people in particular regarding sexuality and reproductive health issues of youth people and can reduce the stigma related to sexuality of youth" As part of project strategy, 22 Youth Groups were formulated all over Pakistan comprising of 10-12 members with gender, religious and ethnic equality. Then CDA Conducted 10 days training workshop on Interactive Theatre for HIV/AIDS Side effects on Youth Sexuality Reproductive Health and Rights in Pakistan for Learning and Practice for each group followed by 10 theatre performances by each group in their respective districts/communities on the said theme to raise awareness about SRHR, reduce stigma about youth sexuality and to promote informed choices among marginalized segment of the society, i.e. youth, women, Madrisah students (Religious Seminaries) and the MSM.

\section{Results}

As a result of the pilot project $1-250$ young activists involved in Sexuality and Health Education from 18 districts of Pakistan 2 - 200 theatre performances staged 3 - 40,000 people from marginalized segment of the society reached and sensitized on Sexuality, health particularly SRH issues and informed choices for better sexual and reproductive health.

\section{Discussion}

Young people posses a great ability to challenge societal norms and bringing change in their own and other peers attitude, knowledge and practices. Through building capacity on innovative and interactive skills, youth activists can play an active role in combating the stigma related to sexuality and can promote health and safer sex practices in marginalized communities. Arts based interventions can be usefully implemented to engage

Correspondence: sanasohail456@yahoo.com

Chanan Development Association (CDA), Lahore, Pakistan 
marginalized communities and generate dialogue even on every sensitive issue like sexuality and reproductive health including SRH.

Involving young activists and employing arts based approaches should have to be ensured in every awareness raising program for reaching marginalized groups and initiating dialogues in very rigid and backwards communities.

Published: 11 May 2010

doi:10.1186/1742-4690-7-S1-P69

Cite this article as: Sohail: Interactive theatre for HIV/AIDS side effects on youth sexuality reproductive health and rights in pakistan to learn and practice. Retrovirology 2010 7(Suppl 1):P69.

Submit your next manuscript to BioMed Central and take full advantage of:

- Convenient online submission

- Thorough peer review

- No space constraints or color figure charges

- Immediate publication on acceptance

- Inclusion in PubMed, CAS, Scopus and Google Scholar

- Research which is freely available for redistribution

Submit your manuscript at www.biomedcentral.com/submit 